\title{
Water quality in hard rocks of the Karkonosze National Park (Western Sudetes, SW Poland)
}

\author{
Henryk Marszałek', Michał Rysiukiewicz \\ 1,2 Zakład Hydrogeologii Stosowanej, Instytut Nauk Geologicznych, Uniwersytet Wrocławski, pl. M. Borna 9, 50-204 Wrocław
}

Record

Hydrogeochemical studies carried out in 2015 record the good state of surface and groundwater quality in the area of Karkonosze National Park.

Abstract

Long-term regional emissions of air pollutants in the second half of the twentieth century led to strong changes in the quality of surface and groundwater in the Karkonosze Mts. As a result, in the most valuable natural parts of these mountains, protected in the area of the Karkonosze National Park, there was strong deforestation, which assumed the size of an ecological disaster. The various protective activities introduced at the beginning of the 1990s led to the improvement not only of the water quality, but also other ecosystems. Based on the chemical analyses of water sampled in 40 points located in the whole Park, the current state of water quality was assessed. Concentrations of some microelements were higher only in few points compared to the drinking water quality standards, which indicates a significant improvement in water quality.

\section{Introduction}

In the second half of the 20th century, the Karkonosze massif has been ecologically heavily damaged by acid rain due to long-term and harmful effects of industrial pollution containing sulphur and nitrogen compounds, resulting from the combustion of lignite in the Żytawa basin. As a result of acid rain, adverse hydrochemical changes, occurred especially in the active groundwater exchange zone, were visible mainly in the 1980s. Acidification of precipitation caused a change in the natural hydrogeochemical background of the selected ions and increased the mobility of many elements, especially some metals. This significantly affected the deterioration of water quality (Kryza et al., 1994, 1995, Marszałek, $1996,1998,2007)$ and a number of adverse changes, including deforestation of large areas of the Karkonosze Mountains. These changes also included the most valuable parts of the Karkonosze, protected in the 5.5 thousand ha area of the Karkonosze National Park (KPN) established in 1959. In 1996, a buffer zone with an area of 11.2 thousand ha was created around the Park (Raj, 2008). The southern boundary of the Park runs along the state border (Figure1).

In the last decades of the 20th century, the impact of human activity on the deterioration of groundwater quality was also observed in other regions of central Europe, including the Czech Republic (Hrkal, 1996; Hrkal, Tajbl, 1997).

The various protective activities introduced at the beginning of the 1990s led to the improvement not only of the water quality,
Keywords

Water quality, hard rocks, Karkonosze National Park, Western Sudetes

Received: 28.11.2017 Accepted: 30.12 .2017

but also other ecosystems. This also resulted in the recovery of the other mountainous ecosystems' condition.

In order to assess the current state of water quality in the area of the Karkonosze National Park, surface- and groundwater were sampled at points located mostly near the Park boundaries (Figure 1). Sampling covered the upper and middle regions of KPN and the lower parts of the mountains at the boundary of the Park and its buffer zone.

The assessment of water quality was based on the results of chemical analysis of main ions and selected microelements. For a more complete illustration of changes in water chemistry in selected areas of KPN, a detailed analysis covered two monitored river catchments: Wrzosówka - draining the central parts of the Park and Łomnica - lying in the eastern part of the Karkonosze Mountains (Figure 1).

\section{Geological and hydrogeological background}

Karkonosze Mts. within the boundaries of the Park are built mainly by Variscan Upper Carboniferous granite. Only in the eastern part, the metamorphic rocks occur, including the Early Palaeozoic series of gneisses and schists (Figure 1). In the main ridge of the Karkonosze Mts, starting from Jakuszyce to Śnieżka, the medium grain granite dominates, whereas the largest spread shows porphyritic coarse granite (monzogranite), occurring in the lower parts of the massif. Characteristic of this type of granite are large, 'henryk.marszalek@uwr.edu.pl; phone: +48605 578107 ${ }^{2}$ michal.rysiukiewicz@uwr.edu.pl; phone: +48608 197493 ə Open Access. (c) 2018 H. Marszałek, M. Rysiukiewicz, published by De Gruyter. (cc)BY-NC-ND This work is licensed under the Creative Commons Attribution-NonCommercial-NoDerivatives 4.0 License. 


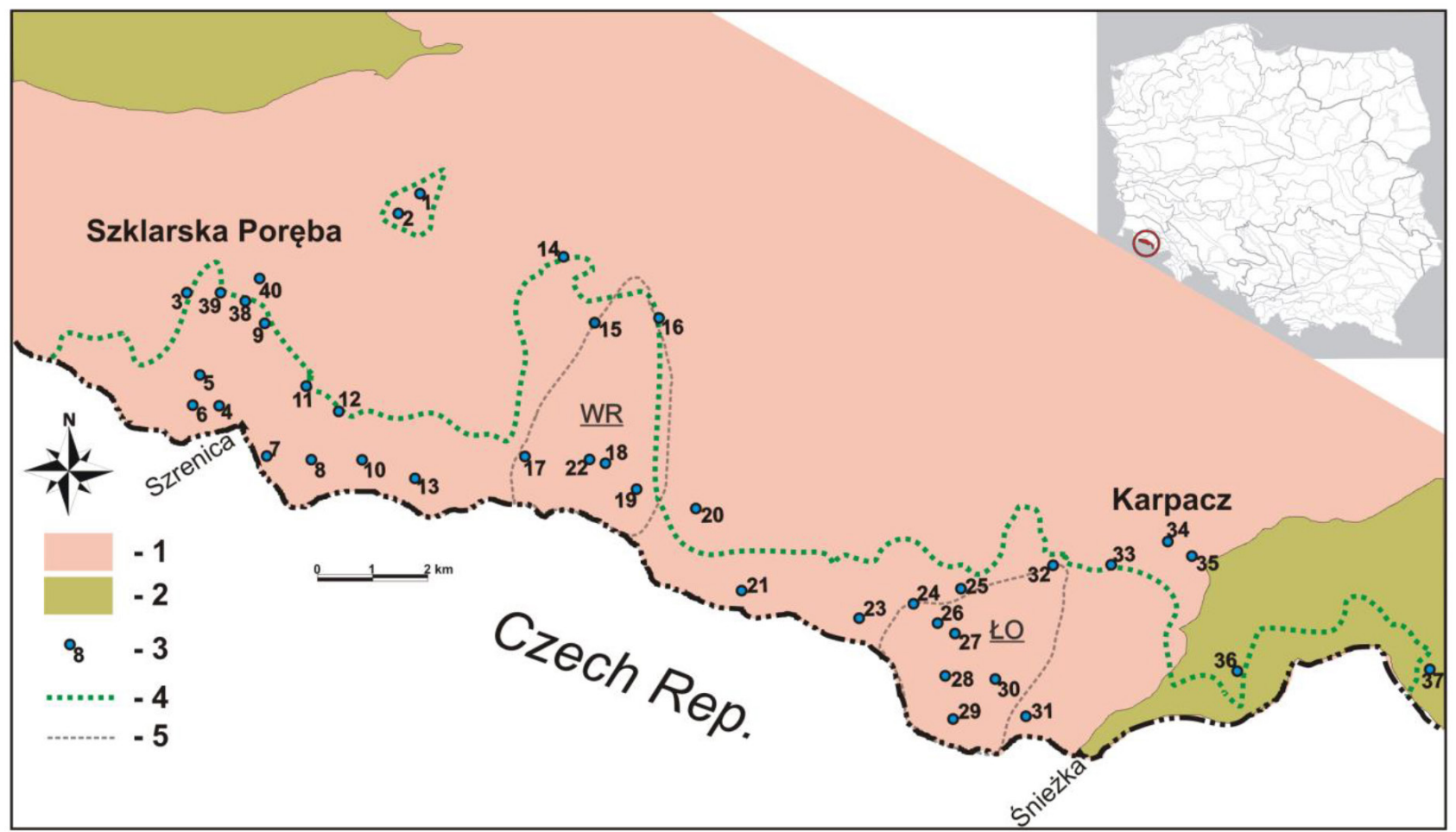

Figure 1. Location of the sampling points on the geology background

1 - granites (Upper Carboniferous), 2 - metamorphic rocks (Early Palaeozoic), 3 -sampling points with number of point, 4 - Karkonosze National Park boundary, 5 - river catchment boundary (WR - Wrzosówka, ŁO - Łomnica)

most often pink in colour, crystals of potassium feldspar occurred in the coarse rock mass composed of feldspars, quartz and biotite. Partly, mainly in the ridges areas of the NE part of the plutonium, fine granite with aplites occurs. Apart from aplites, other veins rocks as pegmatite, quartz and lamprophyres cut the granitic massif. The presence of cataclasites, mylonites and breccia is characteristic for dislocation zones within granite, mainly with NW-SE and SW-NE directions (Mierzejewski, 2005).

The crystalline basement, fissured to various extents, is covered by a thin layer of quaternary clastic rocks expressed by weathering residuals, river alluvial sediments and organogenic deposits (peats). Typical weathering profile of granite, with average thickness of $3 \mathrm{~m}$, consists of well permeable sandy gravel grus saprolite covered by deluvial clayey slope deposits. The majority of summits in the ridge zone of the Karkonosze Mts. is covered by rock debris.

The Polish part of the Karkonosze Mts. is drained by the Kamienna and Łomnica River systems, flowing into the Bóbr River in the morphological depression of the Jelenia Góra Basin. The southern border running along the Karkonosze plateau is the European watershed, separating two river basins: the Odra and the Elbe.

Karkonosze Mts. have the character of an elevated hydrogeological massif, in which forming of groundwater resources depend on the ability of water accumulation by rocks and the climatic features of the area. The occurrence of a well-developed network of fractures in the upper part of the massif, together with the weathering cover, determines the presence of a basic porous-fissure water aquifer (called the Karkonosze aquifer, among others Marszałek, 2007; Kryza et al., 1994, 1995) to a depth of about $30 \mathrm{~m}$. The crystalline massif is fissured to a various extent. The anisotropy of fissured hard rocks is responsible for the water-bearing capacity. The values of the fissured hydraulic conductivity estimated by pumping tests are rather low and amount $0.1-0.80 \mathrm{~m} / \mathrm{d}$ in average and their transmissivity is mainly within $1-40 \mathrm{~m} / \mathrm{d}^{2}$ and rarely reaches $100 \mathrm{~m} / \mathrm{d}^{2}$ (Marszałek, 2007).

The strong morphological diversity of the Karkonosze Mountains favours the existence of a significant number of springs, occurring mainly in the 600-1000 m altitude range. They are characterized by low discharge, usually in the range of $0.1-0.5 \mathrm{l} / \mathrm{s}$.

\section{Methods}

In order to assess the water quality at the whole KPN area, 40 water samples were collected during the dry season of August 2015 (Figure 1). Water samples for the chemical analysis were taken from the spring zone in the upper parts of the Park and from streams at the boundary of the protected area. This series of sam- 
ples was completed with the results of water chemistry analyses for 24 water samples collected in the area of the two monitored catchments (Wrzosówka and Łomnica) at the beginning of July and at the end of October 2015. In this case, water was taken from springs, piezometers and streams.

The basic physico-chemical parameters of water such as temperature, $\mathrm{pH}$, electrolytic conductivity (Cond.) and redox potential (Eh) were measured on-site using calibrated portable WTW 340 multiparametric meter with precision of measurements: $0.01 \mu \mathrm{S} / \mathrm{cm}$ for Cond. and 0.01 for $\mathrm{pH}$.

Chemical analyses of the water sample were made at the Chemical Laboratory of the Institute of Geography and Regional Development of the University of Wrocław using various analytical methods. Alkalinity was measured in the laboratory by colorimetric titration with $\mathrm{HCl}$. Basic ions as $\mathrm{Cl}^{-} \mathrm{SO}_{4}{ }^{2-}, \mathrm{NO}_{3}{ }^{-}, \mathrm{NO}_{2}{ }^{-}, \mathrm{NH}_{4}{ }^{+}$and $\mathrm{PO}_{4}^{3-}$ were determined using spectrophotometric method. For other major ions such as $\mathrm{Ca}^{2+}, \mathrm{Mg}^{2+,} \mathrm{Na}^{+}, \mathrm{K}^{+}$and metals, including Fe, Mn plus selected trace elements, Atomic Absorption Spectrometry (AAS) was used.

\section{Results and discussion}

The conducted studies of the surface and groundwater chemistry in the KPN area indicate no major differences in their ionic composition. It is caused by a constant supply of streams by groundwater, especially during the dry season. The similarity in the ionic composition of both types of waters also results from the fact that the investigations were carried out in the upper part of the massif. Mostly, the chemistry of groundwater in the KPN area is typical for the highest parts of the Karkonosze.

Groundwater in the KPN area belongs to low-mineralization waters, often below $100 \mathrm{mg} / \mathrm{L}$. In the highest, ridges parts of the Karkonosze, water mineralization drops even to a few $\mathrm{mg} / \mathrm{L}$. Then it has the features of rainwater. The average water mineralization of $28 \mathrm{mg} / \mathrm{L}$ (Marszałek, 1996), determined in the mid-1990s for the Karkonosze National Park, was significantly lower than the hydrogeochemical background for the whole Karkonosze, ranging from 42-128 mg/L (Kryza et al. 1994, 1995). The analyses carried out in 2015 confirmed the low degree of water mineralization in the Park area. Mineralization, expressed in the form of electrolytic conductivity (Cond), ranged from 17.6-280.2 $\mu \mathrm{S} / \mathrm{cm}$ (Figure 2). Anomalously high electrolytic conductivity value, registered at one point only (outflow No. 5 below the shelter at Hala Szrenicka), significantly differs from the other values and is almost 3 times higher than the highest mineralization found for the remaining 39 water samples, amounting to $101.8 \mu \mathrm{S} / \mathrm{cm}$. High content of nitrogen compounds $(47.15 \mathrm{mg} / \mathrm{L})$ indicates anthropogenic pollution of water below the shelter. The average conductivity value of the KPN waters is $38.7 \mu \mathrm{S} / \mathrm{cm}$, but when the highest value for point No. 5 will be rejected, it decreases to $31.7 \mu \mathrm{S} / \mathrm{cm}$. The mineralization values of waters sampled in two monitored river

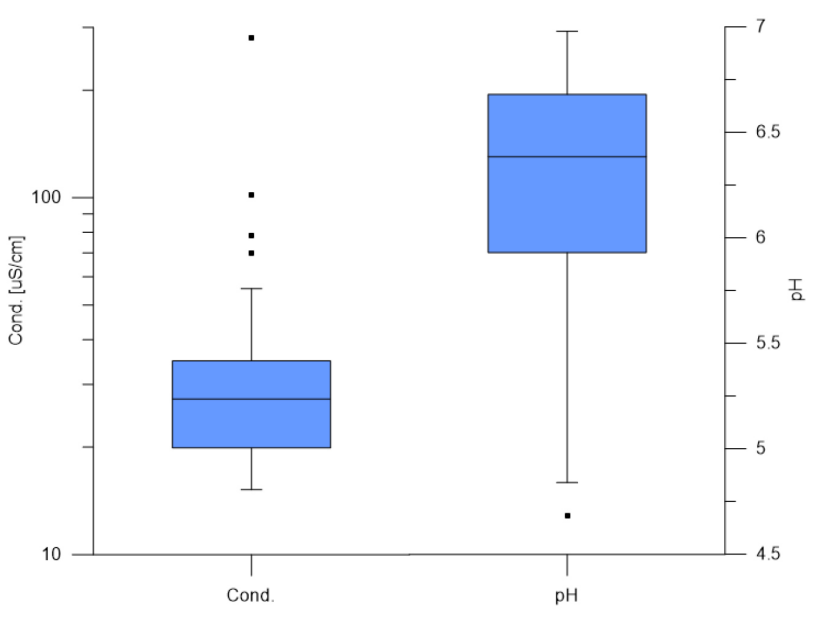

Figure 2. Electrolytic conductivity (Cond.) and pH of water (August 2015)

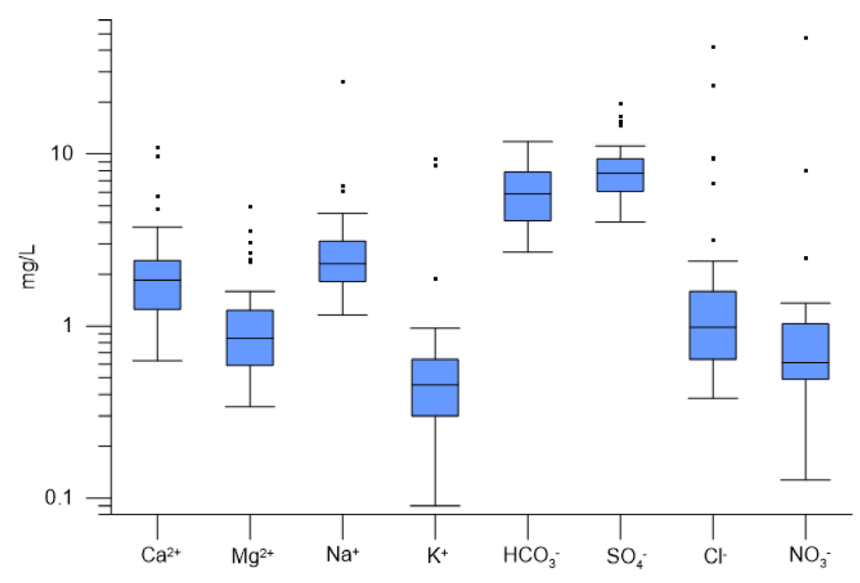

Figure 3. Selected statistical parameters of microelements concentrations in waters of the study area (August 2015)

catchments (Wrzosówka and Łomnica) were within the range determined for the August series. The electrolytic conductivity of the waters monitored in July was in the range of 15.2-69.6 $\mu \mathrm{S} / \mathrm{cm}$ for the Wrzosówka River catchment and 23.9-96.2 $\mu \mathrm{S} / \mathrm{cm}$ for the Łomnica. Slightly higher values had water samples representing the autumn series with a maximum Cond. of $88.4 \mu \mathrm{S} / \mathrm{cm}$ measured in one of the intakes in the Wrzosówka River catchment. Such low contents of dissolved components result from the short residence time of water in the well-permeable rock environment of the upper parts of the Karkonosze granite, represented mainly by rock debris, sandy gravel grus saprolite and heavily fractured upper parts of the massif (Kryza et al., 1995; Marszałek, 2007). The $\mathrm{pH}$ of the KPN waters measured in 2015 was in the relatively narrow range 4.84-6.98 (Figure2). Only in two points, the $\mathrm{pH}$ value was lower than 5 . They are therefore slightly acidic and close to neutral. The average $\mathrm{pH}$ value is 6.18 (Table 1). The water $\mathrm{pH}$ 
Table 1. Chemical composition of water in the Karkonosze National Park (August 2015)

\begin{tabular}{|c|c|c|c|c|c|c|c|c|c|c|c|c|c|}
\hline \multirow{2}{*}{$\begin{array}{c}\text { Statistical } \\
\text { parameters }\end{array}$} & \multirow{2}{*}{$\begin{array}{l}\text { Cond. } \\
\mu \mathrm{S} / \mathrm{cm}\end{array}$} & \multirow{2}{*}{$\begin{array}{c}\text { TDS } \\
\mathrm{mg} / \mathrm{L}\end{array}$} & \multirow{2}{*}{ pH } & $\mathrm{HCO}_{3}^{-}$ & $\mathrm{SO}_{4}{ }^{2-}$ & $\mathrm{Cl}^{-}$ & $\mathrm{NO}_{3}^{-}$ & $\mathrm{NO}_{2}^{-}$ & $\mathrm{NH}_{4}^{+}$ & $\mathrm{Ca}^{2+}$ & $\mathrm{Mg}^{2+}$ & $\mathrm{Na}^{+}$ & $\mathbf{K}^{+}$ \\
\hline & & & & \multicolumn{10}{|c|}{$\mathrm{mg} / \mathrm{L}$} \\
\hline $\min$ & 15.2 & 10.0 & 4.68 & 2.38 & 4.01 & 0.38 & 0.13 & $<0.005$ & $<0.01$ & 0.63 & 0.33 & 1.16 & 0.09 \\
\hline $\max$ & 280.2 & 160.0 & 6.98 & 11.78 & 19.49 & 41.54 & 47.15 & 2.99 & 4.03 & 10.82 & 4.93 & 26.16 & 9.27 \\
\hline mean & 38.7 & 26.0 & 6.18 & 6.03 & 8.54 & 3.21 & 2.08 & 0.11 & 0.13 & 2.41 & 1.15 & 3.20 & 0.92 \\
\hline median & 27.8 & 18.0 & 6.35 & 6.00 & 7.72 & 0.98 & 0.60 & 0.01 & 0.03 & 1.85 & 0.85 & 2.00 & 0.46 \\
\hline $\begin{array}{l}\text { standard } \\
\text { deviation }\end{array}$ & 43 & 25.3 & 0.57 & 2.0 & 3.53 & 7.52 & 7.41 & 0.47 & 0.63 & 2.17 & 0.96 & 4.0 & 1.88 \\
\hline
\end{tabular}

Table 2. Concentration of the selected quality indicators and microelements in waters of the Karkonosze National Park (August 2015) BOD - Biochemical oxygen demand

\begin{tabular}{|c|c|c|c|c|c|c|c|c|}
\hline \multirow{2}{*}{$\begin{array}{l}\text { Statistical } \\
\text { parameters }\end{array}$} & $\mathrm{PO}_{4}^{3-}$ & BOD & $\mathrm{Fe}$ & Mn & $\mathrm{Cu}$ & $\mathbf{P b}$ & $\mathrm{Zn}$ & Al \\
\hline & \multicolumn{4}{|c|}{$\mathrm{mg} / \mathrm{L}$} & \multicolumn{4}{|c|}{$\mu g / L$} \\
\hline $\min$ & $<0.01$ & 0.01 & $<0.005$ & $<0.005$ & $<0.01$ & $<0.01$ & $<0.01$ & 7.93 \\
\hline $\max$ & 3.46 & 12.2 & 0.905 & 0.153 & 10.25 & 10.45 & 89.43 & 831.2 \\
\hline mean & 0.176 & 1.18 & 0.085 & 0.014 & 0.79 & 0.49 & 3.99 & 177.8 \\
\hline median & 0.037 & 0.63 & 0.028 & 0.001 & 0.24 & 0.07 & 0.86 & 88.57 \\
\hline standard deviation & 0.61 & 2.66 & 0.18 & 0.03 & 1.85 & 1.69 & 14.33 & 203.9 \\
\hline
\end{tabular}

measured periodically in previous years at various points of the Karkonosze Mts. showed a decrease in its value of this parameter along with the height of the terrain. Low $\mathrm{pH}$ of waters (even below 4) are typical for watershed parts of these mountains, while close to neutral value (6.5-7.0) have water occurring in the zones of intramontane depressions and river valleys. The $\mathrm{pH}$ of spring waters measured in the 1980s in the western parts of the Karkonosze ridge, in the area between the Szrenica and Mumlawski Wierch, was lower than 3 (Marszałek, 1996).

The acidic $\mathrm{pH}$ of waters in the Karkonosze Mts. lowers their quality. The $\mathrm{pH}$ values of waters measured in July 2015 ranged from 4.48-5.46 for the Wrzosówka River catchment and 4.59-5.85 for the Łomnica catchment. Higher pH values (5.18-9.72 for the Wrzosówka River catchment and 5.63-6.83 for the Łomnica catchment) had waters analysed in October 2015. Anomalously high $\mathrm{pH}$ value of 9.72 had water sample of one intake in the Wrzosówka River catchment. Unnaturally high for the Karkonosze massif, the alkaline value of the $\mathrm{pH}$ was probably related to the use of some carbonate minerals for the water treatment purposes. The lowest values of $\mathrm{pH}$ have mainly waters in the area of peat bogs occurrence in the upper ridges parts of the Karkonosze Mountains.

The ionic composition of waters is dominated by sulphates (often over $60 \%$ of the anion composition), bicarbonates, sodium and calcium. Sodium is sometimes displaced by magnesium. Only in three samples (No. 5, 17 and 32), the main anions are chlorides. This macrocomponent is not typical for the rock environment of the Karkonosze Mts. and its origin is connected with its supply to waters as a result of human activity. Despite its low concentrations ( $3.21 \mathrm{mg} / \mathrm{L}$ on average; Table 1 ) in several samples, it is the second anion due to its value related to the low mineralization of the analysed waters. As a result, we have various hydrogeochemical types of waters from 3- to 5-ionic, with the predominant $\mathrm{SO}_{4}-\mathrm{HCO}_{3}$-Ca-Na-Mg type (Figure 4).

Low mineralization of waters recharged by rainwater, sometimes loaded by portions of pollution, affects a significant fluctuation in chemical composition, resulting in a change in their ionic composition and in the hydrogeochemical type of water. The ionic composition of waters of two monitored catchments analysed in July and October 2015 was dominated by bicarbonates, calcium and sodium. Thus, these waters mainly represent the hydrogeochemical type $\mathrm{HCO}_{3}-\mathrm{Ca}-\mathrm{Na}$ or $\mathrm{HCO}_{3}-\mathrm{Na}$ (Figure 5), and therefore, differ in the case of anions from the composition of waters analysed for the entire area of the Park, in which the sulphate ion dominates.

A wide range of macro- and microelement analysis allows to assess the state of water quality in the entire area of the Park. Important indicators of pollution are mainly sulphur compounds, nitrogen, chlorides and trace elements, including metals. Exceeded concentrations of some elements in rela- 


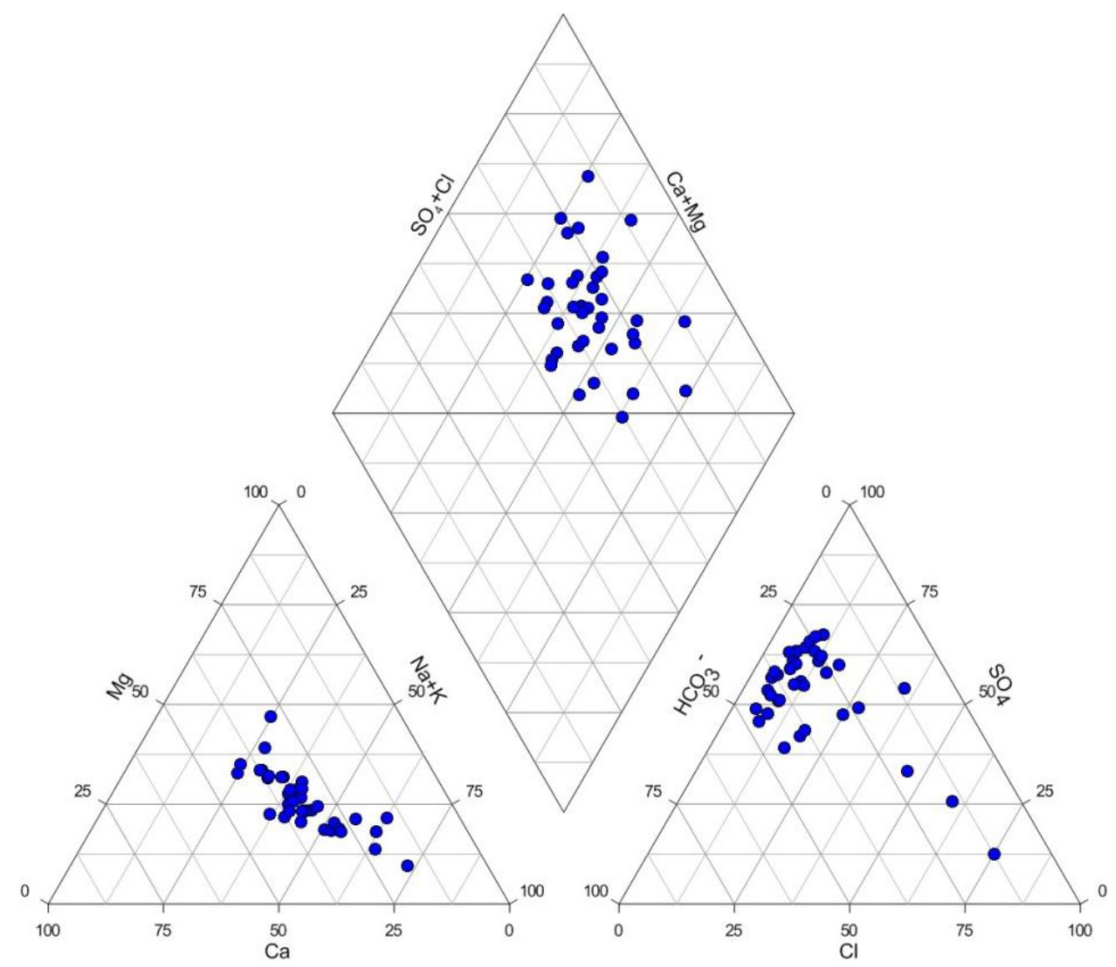

Figure 4. Chemical composition of waters in the Karkonosze National Park for the period of August 2015 presented on Piper diagram

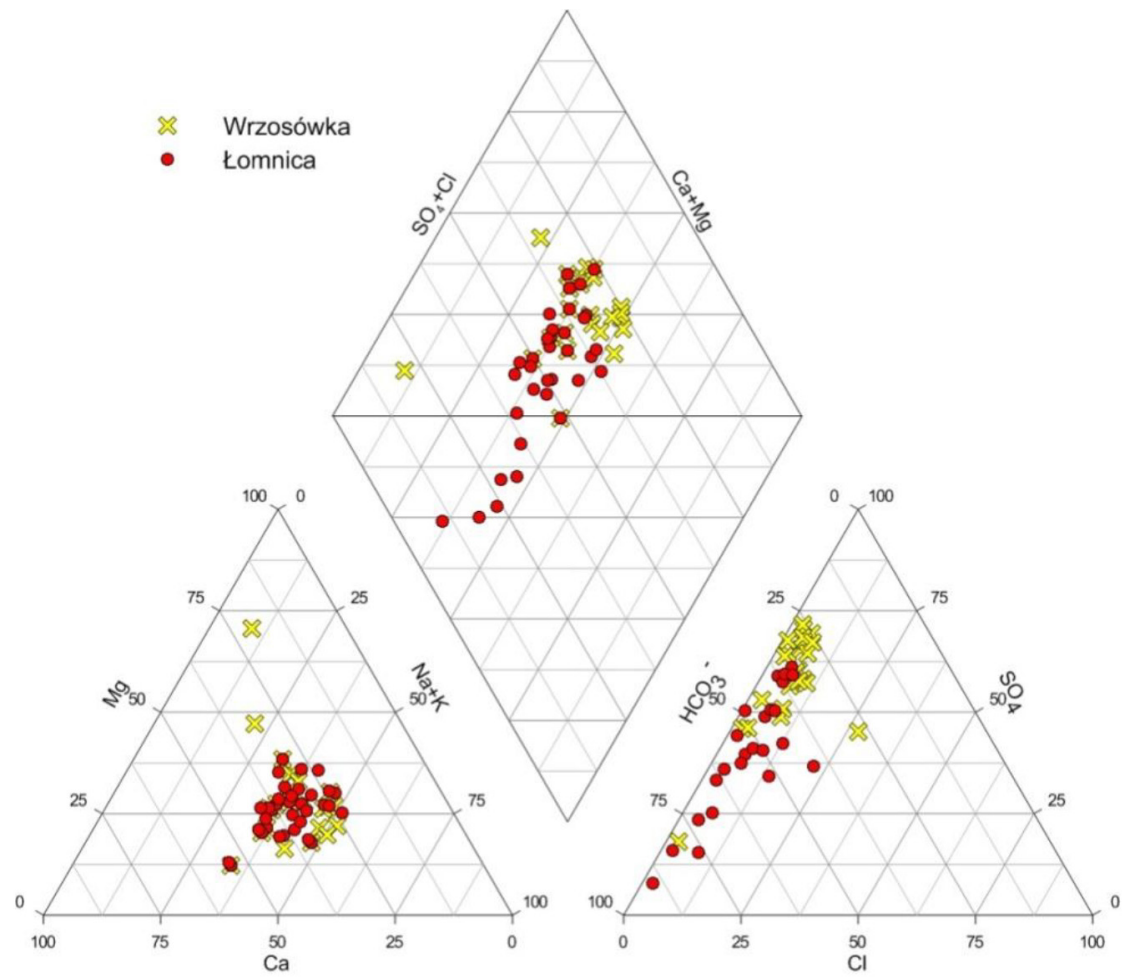

Figure 5. Chemical composition of waters in the Wrzosówka and Łomnica River catchments presented on Piper diagram (waters sampled in July and October 2015) 
tion to drinking water standards, in the entire population of 40 samples was specified only in a few points. This applies mainly to the mentioned outflow No. 5, in which the increased content of nitrogen compounds was found, including more than $47 \mathrm{mg} / \mathrm{L}$ of nitrates, almost $3 \mathrm{mg} / \mathrm{L}$ of $\mathrm{NO}_{2}$ and more than $4 \mathrm{mg} / \mathrm{L}$ of $\mathrm{NH}_{4}{ }^{+}$ion (Table 1). At this point, the maximum content of chlorides and phosphates is $41.54 \mathrm{mg} / \mathrm{L}$ and $3.46 \mathrm{mg} / \mathrm{L}$, respectively (Table 1, 2).

The contents of selected metals are generally low. Apart from the exceeded concentrations in relation to the standards for drinking water (Rozporządzenie..., 2015) in several points for Fe (up to $0.90 \mathrm{mg} / \mathrm{L}$ ) and $\mathrm{Mn}$ (up to $0.153 \mathrm{mg} / \mathrm{L}$ ) located mainly in the central part of the KPN, high Al ion, in the wide range from 7.93 to almost $831.2 \mu \mathrm{g} / \mathrm{L}$ contents, were measured. The average concentration of aluminium in the KPN waters is $177.8 \mu \mathrm{g} / \mathrm{L}$. In 8 samples, the concentration of $\mathrm{Al}$ ion exceeded the acceptable value for drinking water of $200 \mu \mathrm{g} / \mathrm{L}$. According to the Polish regulations, acceptable concentrations for Fe and $\mathrm{Mn}$ in drinking water are $0.2 \mathrm{mg} / \mathrm{L}$ and $0.05 \mathrm{mg} / \mathrm{L}$, respectively (Rozporządzenie..., 2015). In case of the July series of water taken from the Wrzosówka and Łomnica River catchments, aluminium concentrations were within a wide range of 34.42-1091.12 $\mu \mathrm{g} / \mathrm{L}$ (Marszałek, Rysiukiewicz, 2015). The occurrence of this component in increased amounts in the waters of the ridge zone of the Karkonosze Mts. is associated with its leaching from the rock environment with a low water $\mathrm{pH}$, whose value decreases with the increase of the terrain altitude. The presence of peat bogs in the ridge zone of the mountains contributes to lower $\mathrm{pH}$ of the waters. It is also possible to supply Al to groundwater with atmospheric precipitation. From the other metals in most samples, there were small amounts of $\mathrm{Cu}$ (up to $10.25 \mu \mathrm{g} / \mathrm{L}$ ), $\mathrm{Pb}$ (up to $10.45 \mu \mathrm{g} / \mathrm{L}$ ) and $\mathrm{Zn}$ (up to over $89 \mu \mathrm{g} / \mathrm{L}$ ). Maximum concentrations of these microelements were measured in point No. 22, located in the upper part of the Wrzosówka River catchment. Occasionally, $\mathrm{Cd}$ and As were determined in the KPN waters. Cadmium was measured only at two points (No. 22 and 33) in amounts of $1.73 \mu \mathrm{g} / \mathrm{L}$ and $0.12 \mu \mathrm{g} / \mathrm{L}$, respectively, whereas arsenic only in point No. 22 in the amount of $25.24 \mu \mathrm{g} / \mathrm{L}$. Comparing the results of the KPN water chemistry analysis from 1985 (Kowalski, Marszałek, 1985), 1995 (Marszałek, 1996) and 2015 , the highest differences are found in the $\mathrm{pH}$ of water. The average value of this indicator was successively increasing from 4.84 in 1985, by 4.96 in 1995 to 6.18 in 2015 year. This indicates a clear improvement in water quality. The positive trend in the improvement of water quality is also confirmed by the low content of metals and nitrogen compounds. Increased concentrations of the latter in selected points indicate unregulated water and sewage management in the surroundings of some objects. Such negative anomalous phenomena have rather punctual than regional character and can be relatively easy to eliminate.
Analysis of the basic ionic composition showed in 2015 the domination of sulphate ion over bicarbonate, as in the 1980s. This is interesting because the dominant trend of the $\mathrm{HCO}_{3}^{-}$ion dominance over the $\mathrm{SO}_{4}{ }^{2-}$ ion was observed in the mid-1990s (Marszałek, 1996).

Analysis of chemical composition, including the concentrations of two important indicators of groundwater circulation depth in aquifers such as fluorine and silica, indicate the sampling of shallow waters, characterizing the local flow. The content of fluorine in all analysed 40 samples did not exceed the value of $0.1 \mathrm{mg} / \mathrm{L}$, while the concentrations of silica in the $\mathrm{SiO}_{2}$ form were in the range of $6.52-17,97 \mathrm{mg} / \mathrm{L}$ (12.88 $\mathrm{mg} / \mathrm{L}$ on average).

Low mineralization of waters and their temperatures varying depending on the air temperature (lower for springs: 7.2-8.7 and higher for surface water: $10.0-14.5^{\circ} \mathrm{C}$ ) confirm the sampling of the first groundwater aquifer occurring in the layer of fissured crystalline massif covered by the weathering residuals.

\section{Conclusion}

The hydrogeochemical studies carried out in the Karkonosze National Park confirmed the good state of surface and groundwater quality. Apart from the few points located mainly in the areas of mountain shelters, there are no significant changes in the chemical composition of the waters. Elevated concentrations of such metals as: Fe, Mn and Al were found mainly in few in the two monitored river (Wrzosówka and Łomnica) catchments.

Groundwater in the KPN area is low-mineralized with $\mathrm{SO}_{4}{ }^{2-}, \mathrm{HCO}_{3}$; $\mathrm{Ca}^{2+}$ and $\mathrm{Na}^{+}$ions predominating in the chemical composition. Their slightly acidic and close to neutral pH in 2015 compared with low average values of this indicator in 1985 and in 1995 (below 5) confirm the improvement of water quality. Hydrogeochemical features of the analysed waters indicate that all the samples represent groundwater of shallow circulation. According to the hydrogeochemical zonality made for the Karkonosze massif at the beginning of 1990s by Kryza et al. (1995), groundwaters in the KPN area belong mainly to the upper watershed zone covering the highest parts of the mountains and partly - in the Wrzosówka River catchment - to the lower zone of local and mixture drainage.

\section{Acknowledgement}

This paper is based on the results of research carried out in the frame of the project 'Long-term climate, hydrological and physicochemical studies in forest mountainous catchments of the Karkonosze National Park', financed from the forest funds managed by the General Directorate of State Forests. 


\section{References}

[1] Hrkal Z., (1996). Impact of atmospheric deposition on the groundwater acidification in mountains areas of the Bohemian Massif. Acta Universitatis Carolinae, Geologia 40: 223-232.

[2] Hrkal Z., Tajbl M., (1997). Impact of atmospheric deposition on the groundwater quality in the Jeseniky Mts. Acta Univ. Wratisl. No 2052, Hydrogeology. Wyd. Uniw. Wroc., Wrocław.

[3] Kowalski S., Marszałek H., (1985). Chemizm wód Karkonoskiego Parku Narodowego. Mat. Arch Zakładu Hydrogeologii ING U.Wr. Wrocław.

[4] Kryza H., Kryza J., Marszałek H., (1994). Zanieczyszczenie wód Karkonoszy. [in]: Fischer Z. (Eds.): Karkonoskie Badania Ekologiczne II, Ofic. Wyd. Inst. Ekologii PAN, Dziekanów Leśny.

[5] Kryza H., Kryza J., Marszałek H., (1995). Hydrogeochemia środowiska wodnego Karkonoszy. [in]: Fischer Z. (Eds.): Problemy ekologiczne wysokogórskiej części Karkonoszy. Ofic. Wyd. Inst. Ekologii PAN, Dziekanów Leśny.

[6] Marszałek H., (1996). Ocena jakości wód w obszarze Karkonoskiego Parku Narodowego. Techn. Poszuk. Geol. 2, Kraków.

[7] Marszałek H., (1998). Quality of groundwater in the Karkonosze granite in the light of monitoring studies. Münchner Geol. Hefte, Reihe B, heft 8, Hieronymus GmbH. München.

[8] Marszałek H., (2007). Kształtowanie zasobów wód podziemnych w rejonie Kotliny Jeleniogórskiej". Acta Universitatis Wratislaviensis No 2993, seria: Hydrogeologia. Wyd. Uniwersytetu Wrocławskiego, Wrocław, pp. 234.
[9] Marszałek H., Rysiukiewicz M., (2011). Raport o stanie środowiska wodnego w rejonie Szrenicy w zachodniej części Karkonoskiego Parku Narodowego wraz z jego otuliną w roku 2010. Arch. ZHS ING UWr. (niepublik.)

[10] Marszałek H., Rysiukiewicz M., (2015). Raport z wykonania zadania: "Długookresowe badania klimatologiczne, hydrologiczne i fizykochemiczne w leśnych zlewniach górskich w Karkonoskim Parku Narodowym w roku (2015). Fundacja dla Uniwersytetu Wrocławskiego, Wrocław.

[11] Mierzejewski M.P., (2005). Karkonosze - ewolucja masywu granitowego. [w:] Mierzejewski M.P., (Eds..): Karkonosze. Przyroda nieożywiona i człowiek. Wyd. U. Wr., Wrocław.

[12] Raj A., (2008). Karkonoski Park Narodowy. Agencja Fot.-Wyd. 'Mazury', Olsztyn.

[13] Rozporządzenie Ministra Zdrowia z dnia 13 listopada 2015 r. w sprawie jakości wody przeznaczonej do spożycia przez ludzi (Dz.U.Poz.1989). 